\title{
VÁZLAT A TERÜLETI TERVEZÉS ÉS A KÖZIGAZGATÁS KAPCSOLATÁRÓL, AVAGY A REGIONALIZÁLÁS A TERÜLETI TERVEZÉS SZEMSZÖGÉBŐL ${ }^{1}$
}

\author{
(Outline of the Relationship Between Spatial Planning and \\ Public Administration, or Regionalisation from the View of \\ Spatial Planning)
}

\section{PFEIL EDIT}

A közigazgatás-tudományt mindig érzékenyen érinti a kérdés, vajon egy adott szervezet adekvát-e azoknak a feladatoknak a megoldásával, amelyekre létrehozták? Még konkrétabban, valamely szervezeti struktúra megfelelő problémamegoldó képességgel rendelkezik-e? Hiszen maguk a szervezetek is dinamikus kategóriák, melyek müködésük során, a különbözö interakciókban és együttmüködési folyamatokban maguk is állandóan változnak.

A szervezetek olyan társadalmi rendszerek, amelyekben személyek meghatározott célok elérése érdekében együttmúködnek. Nyilvánvalóan egy komplexebb problémamegoldó eljárás szabályozását és rendezését szolgálják, ennek érdekében tagjaik résztevékenységét koordinálják. Feladatok és hatáskörök hozzájuk telepítésével mód nyílik különféle funkciók ellátására, információs csatornák létesítésére, kooperációs folyamatok irányítására, az egyes résztvevők teljesítményének összebékitésére stb. Másfelől a szervezetek kizáró mechanizmusokat is megtestesítenek, azaz csak meghatározott cselekvési lehetőségeket engednek meg, míg másokat ezekkel szemben kizárnak. Azáltal, hogy a kollektiv problémakezelés számára premisszákat állitanak fel, a szervezet tagjainak cselekvési és döntési lehetőségeit leszúkítik. E szelekciós hatás elsősorban a „komplexitás redukciójának” értelmében valósítja meg a problémák feldolgozását, továbbá az információáramlás és az érdekek becsatornázásán, valamint a szervezeti tagok magatartásának irányításán keresztül a tervezési és döntési folyamat eredményeit erösen befolyásolja.

A szervezeten belüli hatalmi viszonyokat a szüntelen instabilitás és a folyamatos változás jellemezheti. Ez az instabilitás annál nagyobb súlyú, minél eröteljesebben fủgg a rendszer a környezetétől. A társadalmi érdek- és hatalmi struktúra döntő változója az állami szervezeti rendszer formáinak és múködési módjának. A belső szervezeti tagolódás, valamint a belső hatalom- és forrásmegosztás a társadalom mindenkori strukturális feltételeit tükrözi vissza. 


\section{A területi tervezés kettős arca}

A szervezet problémamegoldó képességét a területi tervezés vonatkozásában tágabb értelemben kell figyelembe venni. Nem csupán a területi tervezés jogosultjának, mint szervezetnek a belső struktúrája lényeges, hanem a tervezésben érintett intézményekkel való kapcsolatai és együttmüködése is, mind az állami, mind a privát szférán belül. Az egyưttmüködés szükségképpen túlnyúlik a közjogi szférán egészen a magánjogi aktorokig. Azaz a területi tervezés szempontjából soha nem egyetlen szervezetrōl esik szó, hanem szervezetek szövedékéről, szervezetek közötti hálóról. Ez a tény a tradicionális felfogást módosítja abban az értelemben, hogy:

- a kiindulási pont már nem az egész rendszer egy meghatározható célja, hanem az egyes szervezetek céljainak és érdekeinek integrálása egy konfliktusokban gazdag eljárás során;

- a hierarchikus szervezeti modellt fel kell adni egy hálózatszerủ strukturális modell javára, amely a szervezetek közötti sokoldalú és komplex kapcsolatok, valamint a rájuk települt hatalmi viszonyok közül kiemelkedik;

- a rendszert nagyfokú rugalmassággal kell felruházni, és csekély mértékủ formalizmusnak szabad csak alávetni (Benz 1982, 18-19).

Tartalmi oldalról a területi tervezés az alternatív cselekvési lehetőségek közötti választásként jellemezhetô. Ezáltal politikai eljárás formáját ölti, ami nem pusztán a döntési és cselekvési alternatívákban fejeződik ki, hanem abban is, hogy a választások egyúttal mindig szükös források elosztásáról hozott döntéseket feltételeznek. Ez kényszerú konfliktusokat eredményez a tervezésre jogosultak és az érintett szervezetek között. A területi tervezés problémamegoldó és konfliktusszabályozó képessége között szoros és kölcsönös kapcsolat mutatkozik a tervegyeztetési folyamatban. Az érdekkiegyenlítés akkor tekinthetö eredményesnek, ha a problémák megoldásához járul hozzá, és nem csupán a konfliktuskerüló kompromisszumkeresést szolgálja. Az utóbbi ugyanis lemondást jelent a területi fejlődés irányításáról. Végül a politikai eljárás sajátos tárgyát az értékfogalmakról való döntés képezi, mely utóbbiak nem objektiválhatók. Éppen ezért a területi tervezés problémamegoldásait azok politikai dimenziójában kell szemlélni, a belsỏ értékválasztásokat a politikai eljárás eredményének kell tekinteni, és akként lehet elfogadtatni.

A tervezés-szabályozási képesség tekintetében ellentmondás adódik. A területi fejlődés irányítása és a területi tervezés problémakezelö-képessége szempontjából ugyanis döntő jelentósége van annak, hogy milyen mértékben tud megváltozott fejlődési feltételekre és új problémahelyzetekre válaszolni. A tervezés eredményeként megszülető terv, koncepció, mint jogi formát öltő, statikus képződmény kell, hogy számot vessen elóre nem tervezhető fejlódési folyamatokkal és azok dinamikájával.

A terveket ugyanis jogi normáknak kell minősítenünk, noha a jogi formát az egyes államok törvényei különbözőképpen értelmezik és szabályozzák (Erbguth 1981). Németországban például a tartományi tervezési hivatal tartományonként eltérōen nevesített megerősítő aktusa által, a törvény értelmében a regionális fejlesztési ter- 
Vázlat a területi tervezés és a közigazgatás kapcsolatáról , avagy a regionalizálás a területi tervezés szemszögéböl Tér és Társadalom 13. évf. 1999/3. 79-99. p.

vek valamennyi tervezésre jogosult közjogi szereplöt kötelezik. Tehát kötelesek tervezési tevékenységưk és intézkedéseik során a regionális tervekben megjelenö célokat messzemenően figyelembe venni.

Másfelöl a tervezés dinamikus társadalmi történésekre terjed ki, éppen ezért folyamatos döntések sokszintủ eljárása. Ráadásul a jövő irányába nyitott, konfliktushelyzetekben felưlvizsgálandó, az új helyzetekhez magát hozzá igazító, és a célmeghatározásokat a felmerülö problémahelyzetekre koncentráló racionális stratégia. A területi tervezés kettőssége tehát abból adódik, hogy egyrészt jogilag kötőtt eszközzel kell egy megvalósításra alkalmas eszköz fölött rendelkeznie, másrészt biztosítania kell az állandóság mellett a kitủzött célok flexibilitását és reakcióképességét az esetleg megváltozott fejlödési irányok vonatkozásában.

A területi tervezés politizáltsága azonban nem pusztán a funkció oldaláról áll fenn, hanem létezik egy másik vetülete is, amely a regionális tervezésre jogosult szervezet felépítésébỏl adódik. A szervezeti forma megválasztása alapjaiban leképezi a kőzponti állam és a regionális szint, illetve rajta keresztül az önkormányzati szféra közötti kapcsolat koncepcióját. A regionális tervezés bizonyos értelemben közvetítö eszköz a kommunális tervezés és az állami tervezés közőtt, amennyiben a területi tervezés céljait régió-specifikus módon a térstruktúra kisebb egységei felé konkretizálja, differenciálja és elősegíti annak megvalósulását (Fürst-Ritter 1993). Ebből adódik a regionális tervezés több feladata közül az egyik, miszerint a helyi önkormányzatok és a különféle ágazatok tervezési tevékenységét és érdekeit integrálja, mindaddig, míg azok területi szempontból relevánsak.

\section{A regionális tervezés szervezeti típusai Németország példáján}

A regionális tervezés szervezetrendszere az utóbbi húsz évben lényeges változásokon ment keresztül Európaszerte, miután a nagy területi reformok az ủj szervezeti felépítés előfeltételeit megteremtették. A folyamat tendenciózusan az államosítás irányába haladt, pl. Németországon belül Hessenben, Észak-Rajna-Vesztfáliában, Rajna-Pfalzban. E fôderatív államberendezkedésủ országban valamennyi tartomány sajátosan intézményesítette a regionális tervezést. Az önkormányzati és az állami szint összekapcsolása egyéni szervezeti megoldásokat eredményezett. Az állam által erőteljesebben orientált szervezeti modellek a hierarchikus irányításon keresztül az állami normatív tervezési elöírásokat nyilvánvalóan keményebben tudják érvényesíteni az önkormányzati és az ágazati elképzelésekkel szemben. Az államosított tervezésnek van azonban a tervezési folyamat hosszát befolyásoló hatása is. Míg Észak-Rajna-Vesztfáliában a regionális tervezés a tervjavaslat megszulletéséig hat évet vesz igénybe, addig ugyanez Bajorországban - a kommunalizált tervezés keretei közepette - csaknem tíz évig tart. Azok a szervezeti modellek, amelyek erösebb önkormányzati meghatározottságúak, hosszabb tervezési időszakot igényelnek az állam által elfogadottaknál már csak azért is, mert az elöbbiek a tervezést eljárásként/folyamatként értelmezik. Ennek következtében fỏ céllá már nem a formálisan 
hatályos regionális terv felállítása válik, helyette az önkormányzatokkal folytatandó párbeszéd fenntartása, és a közben teritékre kerülö kérdések széles palettája nyomul elötérbe. Egy formálisan érvényessé vált terv hátrányosan is hathat, miután túl sok politikai eröt köt meg. Ezért fordult elö, hogy a tervezök a terveket javaslati állapotban tartották mindaddig, míg lehetséges volt. Ez az államilag meghatározott regionális tervezés esetén nem fordulhat elő, mert ott erös a nyomás a tervek elkészítésére. Amikor viszont a tervezés ,folyamattá” válik, és a konkrét problémákhoz illeszkedik, a formális szervezet szerepe nehezen ítélhetỏ meg. Ekkor mindenekelött a források lépnek elő központi szereplövé, melyek fưggvényében alakul a tervezés mélysége, információkkal való ellátottsága, koncepcionális volta. Ebben a tekintetben a szervezeti modellek nagyobb különbségeket mutatnak.

A modellek egységesek abban, hogy az önkormányzatok tevékeny részvételét biztosítják a területi tervezési folyamatban. Ennek fontossága abból adódik, hogy a helyi területhasználatot, a településrendezést a területi tervezés útján irányítani szükséges, ugyanakkor az önkormányzati jog, illetőleg annak egyik lényegi elemét alkotó önkormányzati tervezési autonómia ennek során nem sérülhet. Németországban tehát a községek és a járások vagy tervezési szövetségekbe tömörülnek, vagy ahol a regionális tervezés állami meghatározottságú, szabályozott eljárás keretében részt vesznek a regionális tervezési eljárásban.

Elöljáróban meg kell említeni, hogy regionális szinten a legtöbb német tartományban szervezeti szempontból elválik egymástól a tervezési és a hatósági/hivatali funkció. A legfelsőbb tartományi tervezési hivatalt középszinten a tartományi tervezési hivatalok képviselik, melyeknek felügyeleti és végrehajtási funkciójuk van. Középszinten e hivatal feladata az ágazati politikák regionális összhangjának biztosítása, koordinálása, amelynek vertikális és horizontális kihatása egyaránt van. Vertikálisan a régió és a központi szint közötti információáramlás javítása, a régiók érdekeinek tartományi szinten, az állami érdekeknek regionális szinten való hatékonyabb megjelenítése a szerepe. Horizontálisan a tervezés során a közigazgatás funkcionális komponenseit (az ágazatokat) kell összekapcsolnia a területi komponenssel, az önkormányzatokkal. A hierarchiában hivatali felettes szerve a belügyminisztérium, míg vele szemben a szakmai felügyeleti jogot a területrendezési minisztérium gyakorolja. Hivatali felügyeleti hatáskörében a tartományi tervezési hivatal elsődlegesen a regionális tervek, koncepciók jóváhagyását végzi. Ez kiegészül a területrendezési eljárás lefolytatásával (ez Alsó-Szászországban kivételesen a járásokra ruházott feladat), a területrendezési kataszter vezetésével. További fontos szerepe, hogy kontrollálja, vajon az önkormányzati telepúlésrendezési tervek megfelelóen illeszkednek-e a regionális tervek által felállított követelményekhez.

Az intézmények vizsgálata elött be kell mutatnunk azokat a különbségeket, amelyek a német regionális illetve területi tervezést tartalmában megkülönböztetik a magyartól. A német regionális tervezésben tartalmilag és intézményesen ötvözödik a területfejlesztés és a területrendezés. A területrendezés az a kulcsfogalom, amely egyfelöl involválja a térhasználattal kapcsolatos különféle, illetöleg egymásnak 
ellentmondó igények koordinációját, másfelöl és egyidejúleg hozzájárul a területi struktúra megfelelö irányú - az elỏzetes értékválasztással adekvát - fejlesztéséhez. A német fogalomhasználat ezáltal hozzárendeli a területrendezéshez a fejlesztési feladatot. A regionális szintủ tervezés tartalmi aspektusa annak alapján itélendö meg, hogy mennyiben van a regionális tervezés abban a helyzetben, hogy a területrendezési problémákat valóságosan megoldja, és a területi fejlödést a kívánatos és célul kitüzött területi struktúrába irányítsa. Ennek érdekében pozícióhoz kell jutnia a területfejlesztést szolgáló pénzeszközök elosztásában.

A hatósági és a tervezési funkció megosztása regionális szinten abban is kifejezésre jut Németországban, hogy a tartományok többségében a regionális tervezés céljait szolgáló régió-lehatárolás eltér az állami középszint (a kormánykerületek) területi beosztásátol, ezért végső soron a tartományi területfejlesztési/rendezési tervet a regionális terveken keresztül a területet lefedő módon konkretizálják és kiegészítik.

A regionális tervezés a gyakorlatban három szervezettípus keretében valósul meg.

- Az önkormányzatok regionális tervezési közösségekbe tömörülnek (Regionale Planungsgemeinschaft). Ennek legtisztább formáját Baden-Württemberg szolgáltatja, mig némileg módosult változatban található meg Mecklenburg-Vorpommern, Rajna-Pfalz, Szászország, Türingia és Brandenburg tartományokban. A tervezési kapacitást állami hivatalok biztosítják ezekben az államokban, Türingiában például a tartományi közigazgatási hivatal (Landesverwaltungsamt), Rajna-Pfalzban a kerületi kormányhivatalnak mellérendelt tervezési hivatal, Szászországban az állami környezetvédelmi szakhivatalok, melyek valamennyi régió számára berendeztek egy tervezési helyet stb. $\mathrm{E}$ tervezési feladatokat ellátó szervezetek általában kizárólag a tervezési közösség utasításaihoz kötöttek. Mecklenburg-Vorpommern a területrendezési- és fejlesztési hivatalaival (Ämter für Raumordnung und Landesplanung) egy érdekes változatot honosított meg, mivel ezek a hivatalok a regionális fejlesztési programok technikai kidolgozásán túlmenően elsődlegesen gondoskodnak a.területrendezési eljárás lefolytatásáról, gondozzák a területrendezési katasztert, illetöleg illetékesek a tartományi tervezési állásfoglalások kiadásábôn

- Az önkormányzatok, vagyis ahogy itt nevezik a községek és kớzségszövetségek tanácsadó és döntési jogkörrel rendelkezỏ szerveket létesitettèk a keruleti kormányhivatalok vagy a kormányelnökség mellett (Bezirksregierung/Regierungspräsidenten), miközben a tervezési tevékenységet a körzeti kormányhivatalok részeként müködő kerületi tervezési hivatalok végzik. Ezt a modellt követik Bajorország, Hessen, Észak-Rajna-Vesztfália és Szász-Anhalt államok.

- Harmadsorban, az Alsó-Szászországban kialakított modell szerint a regionális tervezés a járások kompetenciájába tartozó feladat. E szervezeti megoldás azonban nem érvényesül kizárólagos módon, mivel a braunschweigi és a hannoveri agglomeráció számára külön szervezetet létesítettek, gyakorlatilag céltársulás formájában, melyekre a regionális tervezés feladatán kívül a tömegközlekedés megszervezését, a rekreáció támogatását és a gazdaságfejlesztést is 
átruházták. A társulási modell messzemenő hasonlóságot mutat a badenwürttembergi tervezési közösségekkel, ezért valójában az elsőként felsorolt kategóriába sorolandó.

Ki kell emelnünk, hogy az alsó-szászországi modell Németországban az egyetlen, amely konzekvensen egy területi köztestület, a járások (a járások község-társulásnak minősülnek jogi szempontból) szintjére helyezi a tervezési és végrehajtási funkciót. 1978-ban a regionális tervezésnek a járások hatáskörébe utalásával azt a közigazgatás-tudományi koncepciót igyekeztek megvalósitani, miszerint a tervezési és a végrehajtási szint egységben müködjön. A területi reformok idején fogant alapelv eredetileg 15 járással számolt, míg a reformok lezárulásával 38 járást hoztak létre a tartományban. A járási jogú városokat ezen túlmenően, tervezési szempontból ugyancsak járásnak tekintik, melyek száma kilenc (Fürst 1987). A regionális tervezés járási szervezetének kiépítésére nem vonatkoznak kötelező előírások, ebben szabadság illeti meg az önkormányzatokat. A járások kétharmada önálló hivatalt alakított ki, mig a fennmaradók a regionális tervezést az ágazatok szintjén integrálták (pl. az épitéshatósági vagy a tájtervezési osztályokba). A járások számára ugyanakkor nem vonzó tevékenység a regionális tervezés, mivel a tartomány rendkívül szoros elöírásai alapján a területi tervezés restrikciós/megszorító tervezéssé formálódott, másfelỏl a járások rendre tiltakoznak a járási fejlesztési tervezés ellen, mivel az a járási vezetők szemében túlzottan rugalmatlan, technokrata, az állam által mérhetetlenül befolyásolható fejlesztést tenne lehetővé. Ennek következtében járási szinten tíz év leforgása alatt sem született meg valamennyi regionális fejlesztési terv. Éppen ezért kísérletek történtek a járási szint fölötti kommunalizált regionális szövetségek/társulások kialakítására.

A csoportosításban nem szereplö Saar-vidék nem ismeri a regionális terveket. Ott ugyanis a regionális tervezést a tartományi fejlesztési tervekbe integrálják. Mégis dolgoznak a tartomány egyes részterületeit lefedő és ágazatokra bontott területrendezési résztervekkel. Schleswig-Holstein államban, noha a tartományi szintü tervek konkretizálása regionális tervek útján történik, a tevékenységet állami szinten a tartományi tervezés végzi öt tervezés-technikai szempontból lehatárolt tervezési körzetre nézve.

$\mathrm{Az}$ ismertetett szervezeti megoldások közös eleme, hogy azok mindegyike egyedül a tervezés, a tervezési döntések meghozatala céljából jött létre, vagyis nincs végrehajtási/megvalósítási funkciója (amennyiben az alsó-szászországi modelltől eltekintünk). Ennek magyarázata, hogy az egyes ágazatok és az önkormányzatok autonómiájának védelmére rendkívüli módon ügyelnek Németországban. Ennek azonban ára van, mivel a tervezés és végrehajtás szétválasztása állandósult koordinációs problémákat vet fel, amit a német szervezetrendszerben nem sikerült kielégítően orvosolni. Hiányzik ugyanis az a megfelelö befolyással bíró eszköztár, amely képes volna a tervek megvalósítóinak együttmüködését motiválni. A regionális szint alap- 
vetöen a meggyözés eszközével rendelkezik a szakágazatok és az önkormányzatok kooperációs hajlandóságának ,kikényszerítésére”.

\section{A kommunalizált regionális tervezés}

Az első típus, a kommunalizált - önkormányzatokra épülő - tervezés legvilágosabban Baden-Württembergben jut szerephez. Ezt a tartományt 12 tervezési szövetségre/társulásra (Planungsverbände) osztották fel, mely szám kiegészül a Bajorországgal közösen intézményesített, következésképpen a tartományi határt átlépó Donau-Iller Regionális Szövetséggel (Regionalverband).

A regionális szövetségek szerves fejlődés eredményeként születtek, minthogy 1951-től kezdődően - Baden-Württemberg tartomány alapítását (1953) megelözöleg - a járások és a községek magánjogi egyesületi formát választva együttmüködésre léptek egymással, hogy a települések, a gazdaság és a szabad területek fejlesztését, továbbá az infrastrukturális döntéseket terưleti szinten hangolják össze. A közigazgatási reformot megvalósító második törvénnyel (Regionalverbandgesetz, 1971) vált a regionális tervezés a tartományi tervezés részévé, és ennek megfelelöen intézményesítették a 12 területet lefedö új kommunalizált regionális szövetségeket, amelyek 1973-tól, mint kőzjogi testületek átruházott állami feladatként végzik a regionális tervezést (Mäding 1987) Az 1983-ban hatályba lépett új területi/tartományi tervezési törvény érintetlenül hagyta öket. A régiók lehatárolása a felsőfokú központok (Oberzentren) vonzáskörzetét követte.

A regionális szövetség saját igazgatási szervezettel és alkalmazottakkal rendelkezik a szövetség igazgatójának irányitásával. Politikai szervei a szövetségi gyưlés és az elnök, melyek mellett kötelezö megalakítani a tervezési bizottságot, illetve lehetöség van továbbiak létesitésére. Fö szerve, a regionális gyưlés a régió lakosságszámának fủggvényében 40-100 tiszteletbeli tagot számlál, akiket a járási tanácsok, a járási fönök, a községi tanácsok és a városi kerületek föpolgármesterei választanak ôt évre. Ily módon az önkormányzati szint legitimációval rendelkező tisztségviselöi alkotják a regionális szint választóit. A passzív választójog két tekintetben korlátozott. Csak az választható meg képviselőnek, aki a tartományi gyülésbe is választható, továbbá lakhelye a régióban található. Tehát a közgyủlési tagoknak nem kell sem a járási, sem a községi tanácsok tagjainak lenniük. A törvény a régió lakossága fủggetlen képviselöinek nevezi öket, nem pedig az önkormányzatok delegáltjainak. A szabályozás ilyeténképpen azt hangsúlyozza, hogy a képviselők a régiót reprezentálják, aminek az egyedi önkormányzati érdekek háttérbe szorítása és a regionális identitás erösítése lenne a feladata. A gyakorlatban ezzel szemben a kettős mandátum a tipikus, a szövetségi gyülésben az önkormányzati tisztségviselök dominálnak. (A gyakorlatban a képviselök több mint 50\%-a vagy a tartományi gyúlés tagja, vagy polgármester és önkormányzati hivatalnok. További 30\%-uk a járási és községi tanácsokból kerül ki.) Ugyanez érvényesül a tervezési bizottság összetételében is. A jelenség értelemszerüen konfliktusokat szül, a lokális egoizmus intenzíven megjelenik a regionális tervezési célok vonatkozásában, illetöleg a regionális szövetségekben 
Heléten rendelkező" önkormányzatok a határozatokat oktrojáltnak érzik orientîtusága, Holott formálisan pártfrakciók szerint müködnek.

A ștuvetség igazgatója vezette munkaszervezet feladata új problémák megoldásának kezdệ̣ényezése, vizsgálatok és koncepciók elkészítése. A regionális szövetségek igazgâtási egységei tartományi szinten egy munkaközösség keretei között kooperálnak egymással.

A regionális szövetségek hatásköre törvényen alapul. Feladatuk a regionális tervek, tájtervezési kerettervek elkészítése a természetvédelmi törvény alapján, de jogukbart áll ágazati és térségi részterveket is felállítani. Részt vesznek a tartományi fejlesquési tervek és ágazati fejlesztési tervek készítésében. Emellett tájékoztatják, és tanácsơkkal lắtják el a településrendezés jogosultjait, a privát tervezóket a területrendezés és a tartományi tervezés követelményeivel kapcsolatban. Jogukban áll területi vonatkozással bíró szaktervek felállításában részt venni, azok módosítását javasolni, valamint bekapcsolódni a területrendezési eljárásba.

A regionális tervek felállítása tetemes munkaráfordítással jár, amit jól illusztrál Baden-Württembergben az az adat, amely szerint a regionális tervezési szövetségek egyike - a tervet elfogadó közgyúlési határozatig - a közérdeket a régióban reprezentáló négyszáz szerepló részvételét biztosította az eljárásban, akik összesen 1500 indítványt intéztek a tervezőhöz, amelyek mindegyikéről dönteni kellett. A tervezési szervezet finanszírozása a járások és a járási jogú városok hozzájárulásaiból és az azt kiegészítỏ állami támogatásból történik.

A baden-württembergi szervezettípust módosító tartományok döntéshozó szervekként intézményesített regionális tervezési közösségeket vagy szövetségeket (Regionale Planungsverbände/Planungsgemeinschaften) hoztak létre, MecklenburgVorpommern és Türingia tartományokban négy, Rajna-Pfalzban és Szászországban öt testületet, ami egyúttal a régiók számát is jelöli. Tagjaikat a járási gyúlések és a járási jogú városok tanácsai választják, miközben a föpolgármesterek és a járási fơnökök (a járások első számú tisztségviselói) hivatalból tagok. Rajna-Pfalzban a községi és városi önkormányzatok képviselete azáltal válik erösebbé, hogy a járási gyủlések a képviselök legkevesebb 50\%-át a helyi önkormányzatok által javasolt jelöltek köziłl kőtelesek megválasztani. Ugyanakkor Türingiában a nem járási jogú önkormányzatok húszezer lakos fölött automatikusan küldik polgármesterüket a tervezési közösségbe. A tervcélok regionális konszenzusának kiszélesítése és a különböző, régióbeli társadalmi érdekek integrálása céljából a tervezỏ szervezetekbe tanácskozási joggal meghívják a társadalmi csoportok reprezentánsait, úm. a kamarák, a környezetvédelmi szövetségek, a munkaadók és munkavállalók szervezeteinek képviselöit.

A tervezés technikai feladatait - a tartományok e csoportjában - az államigazgatáshoz, illetve a tartományi közigazgatás mellé rendelt adminisztratív szervek teljesítik. Noha Rajna-Pfalzban a tevékenység irányítója tartományi a hivatalnok, kinevezéséhez és felmentéséhez a tervezési közösség egyetértése szükséges, illetve kizárólag 
az utóbbi utasításaihoz kötötten végzi munkáját. A tervezés adminisztrációját a tartomány finanszírozza.

A kommunalizált regionális tervezés specifikus vonásait tőbbféleképpen értékelte már eddig is az irodalom. Általában a regionális tervezés legmodernebb mo ozatának tartják. Összehasonlítva az ún. államosított regionális tervezéssel Fürst | FürstRitter 1993) előnyős vonásai között említi, hogy jobb helyzetben van az önkormányzatok és a regionális tervezés kőzötti egyưttműkődés serkentése szempontjából, kielégíti a tervezésnek az aktivv, probléma- és folyamatorientált megvalósítása iránti igényt, nyitottabb az ujj kérdésfelvetések irányába:

- Minél egyértelmübb a regionális tervezés önkormányzati meghatározottsága, annál inkább értelmezhetơ úgy, mint a régió irányítási és fejlesztési rendszere, $\mathrm{s}$ annál kevésbé jellemezhetô a tartományi vagy állami tervezés végrehajtó szerveként. Ennek következtében az önkormányzatok inkább hajlanak a regionális terv alkalmazására, semhogy az állami szerveket ostromolják folyamatos követeléseikkel. A szervezeti fulggőség természetesen, mint mindenütt, itt is kapcsolódik a finanszírozóhoz. Ha a regionális tervezést az önkormányzatok fizetik a járási hozzájárulás formájában, akkor a tervező erősebben kötỏdik a községekhez és városokhoz. Ritkább az a megoldás (Rajna-Pfalz), amikor tartományi hivatalnok a tervezö.

- A kommunalizált tervezés szorosabb kapcsolatot létesít a regionális és a településtervezés között, mivel az utóbbi a regionális tervezés egyik megvalósító-végrehajtó szervezete. Mäding (1987) szerint hátránya ugyanakkor, hogy meglehetős távolságban van az ágazati hatáskörök hordozóitól, ami megnehezíti a tervek ágazati átültetését.

- Minél inkább kommunalizált a tervezés, annál egyértelmübb koncepcionális karaktere, miközben a megvalósítás feladatát elhanyagolja. Megfordítva, minél jobban integrálódik a regionális tervezés az államigazgatás középszintjébe, annál inkább elótérbe kerull az állami tervezést végrehajtó funkciója, s ezzel együtt strukturális konfliktusok adódnak abból, hogy a községek és járások már nem érzik magukénak a terveket, egyre kevésbé identifikálódnak azokkal.

\section{Az állami középszintbe tagolt tervezés}

A tartományi tervezés hatékonyabb érvényesíthetősége kedvéért Bajorország, Hessen, Észak-Rajna-Vesztfália és Szász-Anhalt tartományokban a regionális tervezés az állami középszintbe (Bezirksregierung, Regierungspräsidium) integrált és államilag megszervezett. A tartományi kormánynak alárendelt tartományi államigazgatási egységek, a kormánykerulletek részét képező tervezési egységek allamonként eltéróen szabályozottak. Ez a kitétel azonban pusztán azt takarja, hogy a technikai tervezést államositották, a politikai akaratképzésnek ekkor is megvan a legitim mechanizmusa.

Észak-Rajna-Vesztfáliában a kormányelnökség egyik részlegeként müködik a regionális tervezést végzó kerületi tervezési hivatal. A régió ez esetben egybeesik a 
kormánykerület területével, melyekböl ebben az államban öt van. Megengedett azonban, hogy a kormánykerületeken belüli területegységekre készüljenek a tervek. A politikai tervezésre a mellérendelt helyzetben levő ún. kerületi tervezési tanácsot (Bezirksplanungsrat) intézményesítették, amelynek tagjait négyötöd részben a járási gyülések és a járási jogú városok választják, míg egyötödüket tartaléklistáról hívják be. A helyek elosztását szabályozott eljárás keretei között a tartományi kormányelnökség végzi úgy, hogy a tervezési tanácsbeli arányok visszatükrözzék a kommunális parlamenteken belüli pártok és választási csoportok erőviszonyait. A képviselöség feltétele ezúttal a községi vagy városi képviseló-testulleti tagság. A dơntéshozatal önkormányzat-feletti jellegének erösítése érdekében a kamarák, a munkaadói szövetségek, a szakszervezetek képviselöit, továbbá a járási fönököket és a járási jogú városok vezetôit tanácskozási joggal meghívják a testületbe. A tervezési tanácsoknak döntési és kezdeményezési kompetenciájuk van. A technikai tervező szervek feladata a területfejlesztési tervek kidolgozása és a hatékony ráhatás, hogy a kormánykerületekben, azaz a régiókban a tartományi tervezés céljait figyelembe vegyék. Észak-Rajna-Vesztfáliában a tervezési egységek mérete miatt súlyponti szerepe van a tervezésben a koordinációnak, ami elsődlegesen a tervezési hivatalokra testált feladat.

A regionális tervezés feladata Észak-Rajna-Vesztfáliában a tartományi fejlesztési tervekre és programokra épülő, és azok céljait megvalósító területfejlesztési tervek elkészitése, továbbá a tartományi területrendezés és területi tervezés célkitüzéseinek végrehajtása, ső́t annak felügyelete. Bloch (1987) ugyanakkor megállapítja, hogy ebben az államban a tartományi fejlesztési tervek jellege olyannyira konkrét, hogy a regionális tervezés számára alig marad valóságos mozgástér. Mivel a tartományi szint általános és egyedi tervezési céljai regionális szinten tovább nem konkretizálhatók, a tervezési hivatalok a községek irányában kơzvetlenül maguk végzik a konkretizálást, kitüzik a feladatokat, majd elemzik és nyilvántartják, hogy a tartomány teruiletfejlesztési célkitüzései kielégítő módon érvényesültek-e. Az államosított tervezési mechanizmusból adódóan a regionális és a tartományi tervezés két garanciális eszköz fơlött is rendelkezik: a területrendezési tervek céljaival ellentétes intézkedéseket és tervezést megtilthatja, az épitési kérelmeket visszaadhatja. Amennyiben a tilalom feltételei fennállnak, a kormányelnơk utasíthatja az engedélyezó építéshatósági hivatalt, hogy fủggessze fel a létesítményt engedélyezỏ döntést.

Hessen tartományban 1980-ig önkormányzati céltársulás formájában hat regionális tervezési közösség tevékenykedett. Miután a régiók térképét átrajzolták - hasonlóképpen Észak-Rajna-Vesztfáliához -, pártpolitikai alapon szervezódó regionális tervezési gyüléseket vezettek be szintén kormánykerületenként, melyekből ebben az államban mindössze három létezik. A tervezési gyúlések tagjai ezúttal is kizárólag a helyi önkormányzati képviselőkből kerülhetnek ki, tehát a legitimációval már rendelkezök közül delegálják a tagokat a járási jogú városok, a járási gyưlések és az 50 ezernél több lakost számláló járáshoz tartozó telepưlések. (A tagok száma a három régióban 30-100 közötti.) A választási szempontok kơzött a pártbefolyás dominál, 
hiszen a tervezési gyülések frakciókban múködnek. A társadalmi érdekek becsatornázója a tanácsadó funkciójú tervezési tanács, amelyben a régiók legfontosabb társadalmi erői kapnak helyet (pl. Dél-Hessen régióban a városok gyülése, a városok és községek szövetsége, az ipar- és kereskedelmi kamarák munkaközössége, az egyesült vállalatszövetségek, a szakszervezeti szövetségek ágazatok szerint, a parasztszövetség, a kézmủves kamarák munkaközössége, a Hesseni Tartományi Jóléti Szövetség, a tartományi munkaügyi hivatal, az agrárbizottság). A tanácsadó szerv inkább vitafórum, mintsem munkaszerv, mivel a gyakorlatban közős ajánlások megfogalmazására a legritkább esetben képes. A politikai döntések elökészitése különböző profilú bizottságokban történik (tervezési vagy föbizottság, környezet- és természetvédelmi, mezö- és erdögazdasági, gazdasági, közlekedés- és energiaügyi, szociális és kulturális bizottság). A frakciók ezen túl informális munkacsoportokban is dolgoznak. A tervezési gyűlés joga, hogy az alacsonyabb szintú tervező szervek irányában állásfoglalást adjon ki, ha annak tevékenysége legalább egy középfokú központ vonzáskörzetére kihat. Hatáskörébe tartozik a regionális fejlesztési terv felállítása és továbbfejlesztése, valamint a regionális területrendezési terv elkészítése és végrehajtása. A regionális tervezési eljárásba a lefelé irányuló koordináció formájában a települési önkormányzatokat kétszer vonják be, először a javaslat elkészítése idején meghallgatásra van joguk, másodszor a nyilvánosság bevonásának fázisában jutnak szerephez (Fritz-Viette 1987).

A tervezési gyưlés adminisztratív apparátusa a kormányelnökség részlegeként mủködik, amely a tartományi tervezés érvényesítése szemszögébỏl jól kiépítettnek tekinthetö. Feladata a tervezés elindulásához szükséges szakma-specifikus adatok begyüjtésétól egészen, a tervezés utolsó fázisában a regionális terveknek a tartományi tervek célkitủzéseivel való harmonizálásának felülvizsgálatáig terjed.

Bajorország a regionális tervezés szervezetrendszerét illetően köztes helyet foglal el Hessen és Észak-Rajna-Vesztfália között. A tervezés adminisztrációja itt is beépül az államigazgatási apparátusba olyképpen, hogy egy-egy hivatal tőbb regionális tervezési szövetséget szolgál ki. Ennek oka, hogy míg a bajor állam hét kormánykerületre tagolódik, addig tizenhét regionális szövetséget intézményesítettek (nem sorolva ide a korábban említett Donau/Iller Regionális Szövetséget). A tervezési szövetségek a társulási jog alapján alakultak, céltársulások. Ennek következtében tagja a régió minden települési önkormányzata és járása. Képviselöiket ezer lakosonként küldik a szövetségbe, így a régió valamennyi városának föpolgármestere, járásának fơnöke és szinte minden község polgármestere jelen van a regionális tervezésben. A szövetségek taglétszáma 67 és 194 között változik. Ez a szervezeti felépítés több sajátosságot eredményez:

- valamennyi szervezettípus közül a legnagyobb mértékủ az önkormányzati egyéni érdekek megjelenése, ami egyúttal a konszenzus kialakitását is megnehezíti. Ez pedig oda vezet, hogy praktikusan a tervezési bizottságok hozzák meg a döntéseket; 
- a regionális tervezési hivatal kevésbé integrálódik és azonosul a régióval, mint más tartományokban, hiszen egyszerre több szövetség adminisztrációját és tervezési tevékenységét végzi;

- a tervezési hivatal pozícioja az ágazati koordináció szempontjából gyenge, mert Bajorországban szervezetileg nem része a tartományi kormányhivatalnak, ezért az államigazgatási szervek kevésbé segítik munkáját (Fürst-Ritter 1993).

A bajor tervezési modellt szokás a leginkább önkormányzatbarátnak nevezni, e modell azonban egyúttal rendkívül politizált is. A regionális tervezési szövetségek felelösek a regionális tervek felállításáért, karbantartásáért, s mint a közérdek megtestesítői közremủködnek a tartományi tervezésben (tartományi fejlesztési program), tagjaik (az önkormányzatok) rendezési tervezésében a területhasznosítási és a beépítési tervekhez adandó állásfoglalásokkal.

Politikai szempontból kettős funkciót töltenek be. Egyrészt döntéshozó testületek abban az értelemben, hogy az önkormányzati közös érdeket testesítik meg az állammal és az ágazatokkal szemben, másrészt politikai viták, konfliktusok színterei. A végső döntések érelemszerủen nem kizárólag tervezési szempontok alapján, hanem politikai kompromisszumoktól meghatározottan születnek. Maguk a testületek el is utasították az önkormányzati szövetségek azon ajánlását, amely szakemberek bevonását javasolta a tervezési szövetségek közgyủlésébe.

Németországban a regionális tervezés központi döntéshozói az önkormányzatok, ugyanakkor azt is látni kell, hogy meglehetősen erös a regionális tervezésre gyakorolt állami befolyás. A közvetlen ráhatás a területfejlesztési és környezeti kérdésekért felelős minisztériumon keresztül valósul meg, hiszen e szerv nem csupán jóváhagyja az ún. kötelezővé nyilvánítási aktussal (Verbindlichkeitserklärung) a regionális terveket, hanem a tervek megalkotását és tartalmát is befolyásolni tudja szervezetí és tartalmi jellegủ normatív keretelöirásokkal, valamint azzal, hogy a tervezési szövetségeket folyamatosan ellátja tanácsokkal. Az ágazati hivatalokat és szerveket a tervkészítés folyamatába többször is bevonják, és felhívják őket szakvélemények, állásfoglalások adására a különböző részterületekre vonatkozólag. Az is az állami vonalat erősíti, hogy noha a regionális tervezés adminisztratív szervei a technikai döntés-elökészítés során a tervezési szövetségek utasításaihoz kötöttek, szervezetileg nem azok, hanem a tartományi knrmányelnökség alá rendeltek, sőt ezen túlmenően a tartományi kormányzat tervezési munkaszerve, a tartományi tervezési hivatal, mint a regionális tervezési szövetségek szakmai felügyeleti szerve, szakvélemény készítésére kötelezheti öket. A technikai tervezés államigazgatási integrációját a munkaszervezés racionalitásával indokolják. Ez számos elönnyel jár, például könnyủ hozzáférés a technikai eszközökhöz, becsatlakozás az ágazati belső információs hálózatba, közvetlen kontaktus az ágazati szervekkel, ami által a szakmai kérdések szolgálati úton tisztázhatók.

Összességében az állami középszinthez telepített regionális tervezés a regionális fejlesztési koncepciókban kevésbé engedi érvényesủlni a parciális lokális érdekeket, ugyanakkor hátránya, hogy a helyi önkormányzati szféra szemében primer állami 
tervezést testesít meg. Ezt úgy élik meg a települések, hogy érdekeik a regionális tervezés során minimalizált mértékben tudnak érvényre jutni, $\mathrm{s}$ a tervezési szövetségekbeli képviselőik pusztán az önkormányzati érdekek sérelmeinek elkerülése felett örködnek. Az ezzel összefüggésben gyengének nevezett regionális identitás Németország említett tartományaiban azt eredményezi, hogy a hatalommal bíró városok érdekeiknek jobban érvényt tudnak szerezni, mivel pártpolitikai befolyásukat, személyes kapcsolataikat használják fel a tartományi kormányoknál fơleg a területhasználat tervezése során (Müller 1987).

A felvázolt struktúrának létezik egy érdekes aspektusa, mégpedig az, hogy az önkormányzati képviseleti szervek (regionális tervezési szövetségek, tervezési tanácsok) kormányhivatalok mellé telepítésével a kormány képviselöi inkább érzik magukat a régió reprezentánsainak az állam érdekeivel szemben, mint maguk a szövetségek, holott elsődleges funkciójuk az állami politika érvényesítése a régióban. Az állami magatartást példázza az is, hogy az ,államosított" tervezési modellek közül a hesseni és az észak-rajna-vesztfáliai számottevő pénzügyi forrás fôlött rendelkezik, míg a települési érdekektől jobban befolyásolt bajor és rajna-pfalzi regionális szövetségek igen rossz anyagi helyzetủek. Végül tendenciaként megfogalmazható, hogy a tervezés a hetvenes évek közepe óta politizálódik, a finális tervezést, amikor egyetlen cél a megrajzolt és leirt terv tárgyiasulása volt, felváltotta a tervezés, mint folyamat elv, amely a tervezést kontinuus viták és problémamegoldások eszközének tekinti, miközben a tervezỏ szerepe is átformálódott. A technokrata diplomatává vált, aki moderátora a regionális probléma-kezelő folyamatnak, elsimítója a területhasználati konfliktusoknak.

A németországi tapasztalatokat összegezve a területi tervezés föderativ felépitésének egyik kiindulópontja, a szövetségi szintủ területrendezési kerettörvény sarokpontjai között a tartományokat megilletö területi tervezési hatáskör, mint saját fennhatóságukba tartozó feladat jelenik meg. E jogosítvány kiterjed a tartomány teljes teruletének területi egységekbe tagolására, attól a céltól vezérelten, hogy valamennyi állampolgár számára megteremtse és fenntartsa az azonos értékủ életkörulményeket. A regionális tervezés, a területi tervezés tartományi szintủ megfelelöje területegységekben (Teilräume) valósul meg a lokális és az ágazati szint feletti tervezés értelmében.

A területegységek, vagyis a tervezési régiók lehatárolása egyes tartományokban (Baden-Württemberg, Bajorország, Rajna-Pfalz, Schleswig-Holstein) funkcionális kritériumok alapján, a felsőfokú központok vonzáskörzetét leképezve, továbbá szociális és gazdasági valamint kulturális tényezőkre is figyelemmel történt. Más tartományokban, Hessenben, Alsó-Szászországban, Észak-Rajna-Vesztfáliában stb. igazgatási szempontok játszottak szerepet a tervezési régiók kijelölésénél, ezért a tervezési és közigazgatási térfelosztás határai fedik egymást. A nagyságrendi különbség - a felsorolt tényezóknek köszönhetően - meglehetősen nagy a régiók szintjén, a 49 ezer lakosú járástól az ötmillió lakost számláló kormánykerületig terjednek 
a méretbeli különbségek. A tervezési régiók száma, pl. az ország nyugati felében 3 és 47 között mozog.

Németország, mint fóderális állam esetében az eddigiek tükrében mit is jelent valójában az EU szempontrendszerét kielégítő régió? Heinrich Mäding válaszában azt mondja, az Európai Unió által megkülönböztetett NUTS 1 szint Németországban a 16 szővetségi tartományt jelenti, míg a NUTS 2 szintnek a kormányzati kerületek (Regierungsbezirke) számítanak. Ez alatt a szövetségi államban NUTS 3 szintként jelennek meg a tartományi tervezési régiók, $s$ a járások alkotják a NUTS 4 szintet (Mäding 1992).

\section{A területi tervezés magyar intézményei}

\section{Következtetések a regionalizálással összefüggésben}

A Magyarországon 1996-ban, gondolatában pedig már az önkormányzati törvẻny 1994. évi módosításával megfogant területfejlesztési intézményrendszer egyértelmủen az Európai Unióhoz történő csatlakozás reményéböl táplálkozott, és látszólag a szervezeti igazodás alapelvén áll. Ha kifejezetten a területi tervezést végzö szervekre koncentráljuk figyelmünket, akkor a szervezeti felépítés egyik rendező elvét a területfejlesztési koncepciók és programok, másikat a területrendezési, illetve végső pontjukban a településrendezési tervek alkotják, mint azok a végsó produktumok, amelyek valamilyen döntéshozó szervet igényelnek. E döntési kompetenciák birtokosai pedig vagy illeszkednek a kőzigazgatás szervezetébe, vagy legalábbis tisztázott az ahhoz, illetve az államhoz füzödö viszonyuk. Többen felhívták már a figyelmet arra a szabályozási zürzavarra, ami abból fakad, hogy a két tervezési szakaszt és az információs rendszert intézményileg elkulönuulten telepítette a törvény. Súlyos következményekkel jár, és szemléletbeli ellentéteket szül a fejlesztési és a rendezési tervezés intézményi elválasztása, továbbá a területi információs rendszer müködtetetésének a megyei őnkormányzatokhoz, míg a fejlesztési tervezésnek a területfejlesztési tanácsokhoz utalása (Rechnitzer 1998).

A területfejlesztési tervek és programok készitöi a területfejlesztési törvény értèlmében regionális és megyei szinten a területfejlesztési tanácsok, a kistérségekben a teruletfejlesztési önkormányzati társulások. A két szervtípus közőtt lényegi különbség van. A társulásokat közjogi jogalanyoknak kell neveznünk akkor is, ha a magyar jogdogmatika máig adós a kỏz- és magánjog határainak pontos megvonásával. A területfejlesztési társulások tagjai ugyanis kizárólag önkormányzatok lehetnek, azokból a törvény kizárja a magánjogi jogalanyok részvételét. A társulás az önkormányzati tơrvény hatálya alá tartozó intézmény. A terưletfejlesztési ơnkormányzati társulás szervezeti jellegéből következően - elsődlegesen abból a tényböl kifolyólag, hogy helyi ơnkormányzatok egyưttmüködését intézményesíti - a közigazgatás struktúrájába illeszkedik, attól nem szakítható el. A terưletfejlesztési tanács noha törvénymódosítás kơvetkeztében kőltségvetési szerv, mégsem minősủl közigazgatási szervnek. 
A terulleti tervezés egyik végpontján tehát az Országgyülés, másik végpontján az önkormányzatok vannak még akkor is, ha a településrendezés és -tervezés egy másik törvényben, az épített környezet alakításáról és védelméröl szóló tơrvényben rendezett kérdés. Az országos, regionális, megyei tervekben elfogadott célok végső soron valamely önkormányzat településrendezési tervében konkretizálódnak. Az Alkotmány értelmében a helyi képviselö-testület önkormányzati ügyekben önálloan szabályoz és igazgat, döntése kizárólag törvényességi okból vizsgálható felül [44/A. § (1) a)]. A területfejlesztés és -rendezés intézményrendszere ily módon az önkormányzati autonómiába, az önkormányzatiság lényegi magvába történỏ beavatkozást valósít meg, amit a jogi norma szintjén fel kellett oldani. Ennek metódusa az Európaszerte elterjedt területi tervezési rendszerekben az - legyen az kommunalizált vagy állami dominanciájú -, hogy az ơnkormányzatok átfogó részvételének joga biztosított a regionális, valamint a központi tervezési eljárásban. A tervek aktiv befolyásolásának lehetősége alapozza meg kötelezettségüket a felsőbb szintü tervek kővetelményeihez való igazodásra, elöírásaiknak a figyelembevételére.

Figyelembe kell tehát venni, hogy bármely szintủ területfejlesztési szervnek a tervezési elképzelései, fejlesztési koncepciója végső soron egy konkrét területre vonatkoznak, konkrét formájukban valamely önkormányzat közigazgatási területét, s általa az adott képviseló-testület tervezési hatáskörét érintik. S minél közelebb esik a telepullési szinthez a területi, annál intenzívebb önkormányzati befolyásolási lehetöséget szükséges biztosítani a legitimáció érdekében. Ez az egyik záloga annak, hogy a területi tervek a szükséges módon helyi szinten is megvalósuljanak. A területfejlesztés azonban csak helyi szint felett értelmezhetö feladat, helyi önkormányzati megfelelöje a településfejlesztés. Az Ötv.-ben az önkormányzatnak az utóbbira van felhatalmazása. A területfejlesztési önkormányzati társulás megalapítása nyilvánvalóan nem a helyi önkormányzati telepủlésfejlesztési hatásköröknek a társulásra ruházásaként definiálandó. Nem beszélve a településfejlesztés egyik végrehajtási eszkőzéről, a telepưlésrendezési tervezésról, mely jogosítványt a törvény egyenesen a képviselö-testület át nem ruházható hatásköreként nevesíti. Éppen ezért a területi tervezés és a közigazgatás feltétlenül összekapcsolódó intézmények, még akkor is, ha Magyarországon a területfejlesztés intézményrendszere látszólag a közigazgatástól kuloonállóan, egy speciális szervezeti formában öltött testet. Legfeljebb a törvényhozó nem vetett számot a területfejlesztési tanácsok intézményesítésekor azokkal a hátrányokkal, amelyek a szervezetrendszer megkettőzésébỏl, az önkormányzati és területfejlesztési tanácsi vonalból adódnak.

A területfejlesztési tanácsokat az önkormányzatok igazából nem érezhetik magukénak, hiszen azok összetételét tekintve nem tudott megvalósulni a törvényhozó állítólagos szándéka, miszerint a kistérségek hangsúlyos képviselettel rendelkezzenek a tanácsokban. A tapasztalatok azt bizonyítják, hogy az erőviszonyok sokkal bonyolultabbak, a tanácson belüli érdekkoalíciók nem állandósulnak, hanem esetröl esetre ủjraszerveződnek. A tanácsok összetétele, múkődési rendje nem tud eleget tenni a politikai felelósségü mérlegelés és döntéshozás kővetelményének (Pálné Kovács 1997). 
Ha a mai magyar területfejlesztési intézményrendszernek a súlypontja áthelyezödne a megyéról a régióra, akkor számot kell vetni azzal is, hogy a helyi önkormányzati szféra részvétele a regionális fejlesztési tanács munkájában a jelenlegi összetétel mellett, elegendő garanciát jelent-e az idézett alkotmányi tétel megvalósításához.

A területi politikának mindenkor szoros kapcsolata van az állam felépítésével és magával a közigazgatás struktúrájával. A területi tervezés szervezetét és az alapjául szolgáló tervezési régiókat figyelembe véve az ismertetett német tartományok által kővetett modellek bizonyos következtetéseket engednek meg. Az egyik csoportot a föderalizált Németország tartományai alkotják, ahol néhány kivétellel (AlsóSzászország, Észak-Rajna-Vesztália) a közigazgatási területbeosztástól független funkcionális régiók, rendszerint a felsőfokú központok vonzáskörzetét lefedö tervezési-gazdasági régiók a regionális tervezés bázisai. Ezekben az államokban a regionális tervezö szerv szükségképpen valamilyen delegációs rendszerben müködö politikai testület. Németország e tartományai maguk testesítik meg a közigazgatási értelemben vett régiót, amelyek magukon viselik az államiság bizonyos jegyeit, $\mathrm{s}$ az állami szintủ (Landesentwicklung) fejlesztés és tervezés gazdái. Németországban ugyanis a területi tervezés első szintje a tartományi, amely autonóm módon maga alakítja ki szervezeti felépítését.

A területi tervezés aspektusából az államok egy másik csoportjába sorolódnak azok, amelyek a regionális tervezést a kőzigazgatás középszintjére telepítették, ahol is rendszerint a közvetlen demokratikus módon választott önkormányzati testületek birtokolják a területfejlesztési és tervezési döntési jogosítványokat. Ennek megfelelöen a decentralizált államberendezkedésủ Franciaországban a közigazgatási régió regionális tanácsa dolgozza ki, és fogadja el a regionális területrendezési és területfejlesztési koncepciót a megye tanácsa, valamint a gazdasági és szociális tanács állásfoglalását követően (Kistenmacher-Clev 1996). Az unitárius államok közül Hollandiára jellemző, hogy a központi állami szint és a helyhatóságok közötti kőzigazgatási megye (provincia) politikai testületének hatáskörébe tartozik a regionális terveknek, mint a megye politikai programjának megalkotása. Bár hozzá kell tenni, hogy noha a megyék politikai legitimációval rendelkeznek, tényszerủen az egységes állam decentralizált közigazgatási egységeinek minősülnek. Az Egyesült Királyságban nyolc programrégiót definiáltak, melyekben regionális hivatalok müködnek. Nézőpontunkból azonban lényegesebb a tervezési struktúra, amely 1968 óta a „development plan” értelmében két szintet fog át. A viszonylag bonyolult brit közigazgatási felépítésen belül Anglia és Wales vidéki térségeiben a megyék (county councils), a városias térségekben a járások („districts”), mint régiók a címzettjei a területi tervezési kompetenciáknak. A közigazgatási szintekre ráépülő „régiók” fejlesztési koncepciót alkotnak, amit a vidéki térségekben a kétszintűséget megvalósítva követ a „local plan”, ellenben a városias térségekben egy egységes fejlesztési terv (Unitary Development Plan) tölti be a két funkciót. A regionális terveket a megyék politikai testületei, a tanácsok fogadják el, a környezetért felelős minisztérium jóváhagyásával. 
Megállapítható tehát, hogy azokban az államokban, amelyekben a közigazgatási/önkormányzati középszint egyúttal tervezési régió szerepkört is kapott, ott a két funkciót, a közigazgatásit és a tervezési döntéshozóit ugyanaz a politikai testület, adott esetben a közvetlenül választott önkormányzati testület tölti be. A vizsgált országokban nem jellemzö, hogy ugyanabban a területi egységben önmagáért a területi tervezésért megkettóznék a szervezeteket, és párhuzamos struktúrákat építenének ki. Ennek hátterében különféle okokat kereshetünk, úgy, mint a takarékosság és racionalitás, ső́t a területi köztestületek minden bizonnyal alkalmasak a területi érdekek artikulációjára, ami kifejezésre jut a tervezési kompetenciák gyakorlásában is. Ahol mégis delegációs elven felépullö speciális regionális tervezési szervezetek léteznek, ott ezeket az a szükségszerüség hívta életre, hogy a tervezési egységeket a valós vonzáskörzetekre, gazdasági régiókra kívánták rászervezni. A közigazgatás területi struktúraját azonban bizonyos mértékig ebben az esetben is tiszteletben tartják némely államok, mint például Bajorország és Rajna-Pfalz, ahol a tervezési régiók lehatárolása során lehetőség szerint érvényesítették a járáshatárok átmetszésének tilalmát.

Magyarországon a tervezési régiók az Országos Területfejlesztési Koncepcióban meghatározott mesterséges képződmények, $s$ a konstituálás első lépcsőjében majdnem elkerülhetetlen volt, hogy regionális szinten jogintézményi szempontból is tisztázatlan ún. területfejlesztési tanácsok szülessenek. A folyamatot a nem is annyira a háttérben zajló, az önkormányzati középszint körül folyó politikai viták indukálták, melyek következtében elöször megyei szinten kettőzték meg a szervezeti struktúrát a területfejlesztési és tervezési hatáskörök némileg zavaros megosztásával. A nemzetközi tapasztalatok birtokában azt mondhatjuk, talán feleslegesen, hiszen az önkormányzati közigazgatás és a területi tervezés középszintli egységeinek határai egybeesnek. Ebben a gondolatmenetben - amennyiben feltételezzük a megyei önkormányzatoknak, mint közigazgatási középszintnek a megtartását - egyáltalán nem szükségszerủ, hogy a regionális szint egyúttal önkormányzati is legyen. Szerves fejlődés hiányában a középszint ilyetén megkettőzése erőszakoltnak tủnnék, másfelöl elemzések már bizonyították (Horváth 1998), hogy azokban az országokban, ahol a helyi önkormányzatok felett két teruleti kơzépszint szerveződött, megfigyelhetơ a hatáskörök szétforgácsolódása. Vagy azért, mert a központi állam a szubnacionális szintek között a hatásköröket úgy osztja meg, hogy azok egyưttmüködésre kényszerülnek, vagy azért, mert a magasabb területi középszintnek csak tervezési funkciókat juttatnak, a döntési hatáskör a központi államnál marad, illetőleg a régióknak a végrehajtásban ugyancsak együtt kell müködniưk az alsóbb szintekkel.

Nálunk egy ilyen jellegú közigazgatási-szervezeti változtatás még megterhelödne a területfejlesztési tanács és az önkormányzat közötti munkamegosztás problémahalmazával is, ami tovább rontaná a viszonyok átláthatóságát. Mindenképpen racionálisabb megoldásnak ígérkeznék a megye önkormányzati szintként való megtartása, s ha „vezéráldozatra” lenne szúkség, akkor a megyei területfejlesztési tanácsok kiiktatása mellett inkább felsorakoztathatók érvek. Ennek a megoldásnak a hátránya, hogy a fejlesztési és rendezési tervezés intézményes kettészakítottságát fenntartaná, 
illetőleg az még megtetéződne a regionális fejlesztési és a megyei rendezési tervezés szintbeli elválasztásával. Az önkormányzati közigazgatás hosszasan vajúdó korszerüsítése, az integrációs csomópontok hiảnya akár a szolgáltatásszervezés, akár a hatósági igazgatás vagy a városok és vonzáskörzetük együttmüködése tekintetében egyelöre drasztikus változtatások árán tenné csak lehetövé a regionális önkormányzati szint létrehozását a megyei önkormányzatok felszámolásával egyidejüleg.

\section{A területi és az ágazati érdekek érvényesülésének keretei}

A tervezés és a tervek megvalósításának, végrehajtásának összekapcsolása a területi tervezés centrális kérdése kell, hogy legyen. A tervezési döntések meghozatalánál figyelemmel kellene lenni azok adminisztratív megvalósíthatóságára, különösképpen akkor, amikor a tervezés, mint problémamegoldó eljárás szervezetileg elkülönül a terveket intézkedésekké alakító államigazgatási szervektöl, a településtervezést megvalósító önkormányzatoktól, valamint a programokat végrehajtó beruházásoktól. Természetesen a tervek és programok tartalma a közigazgatási szereplök mozgásterét nem determinálják teljes mértékben, megfelelỏ mozgásterük, alkalmazkodási és módosítási lehetőségük van a címzetteknek.

A tervek megvalósítása szempontjából a magánjogi szereplök mellett igen nagy súllyal esik latba a közjogi szektor alanyi köre, az önkormányzatok és a területi államigazgatási szervek. Noha egyelöre sok bizonyítéka nem látható annak, hogy területi szinten ágazati fejlesztési koncepciók készülnének. Kivételként említhetök a megyei foglalkoztatási koncepciók a megyei Munkaügyi Tanácsok gondozásában.

A dekoncentrált szervek más megitélés alá esnek, azok illetékességi területének a hét statisztikai-tervezési régióhoz történö igazítása nem ütközik különösebb akadályokba, sőt kívánatos. S tudni lehet, hogy egy ilyen irányú racionalizálási folyamat már kezdetét vette. Ennek a tendenciának azért lehet a késöbbiekben pozitiv hatása, mert a Tft.-ben a területi államigazgatási szervek is feladatot kaptak a térségi fejlesztés és tervezés koordinációjának vonatkozásában, ami szakmai segítségnyújtást és az információszolgáltatást öleli fel. S ebben a tekintetben nem mellékes körülmény, hogy a területi és az ágazati érdek és szemlélet ugyanabban a területi egységben artikulálódik.

A területfejlesztési koncepciók alapvetően céltervek, azok végrehajtásának eszközei legkevesebb két csoportot ölelnek fel. Egyfelöl a támogatási eszközöket, vagyis a pénzügyi ösztönzőket, valamint a befolyásolás puha eszközeit, úm. az információszolgáltatást, a meggyőzést, a tárgyalást stb. Másfelöl a területhasználati funkciók (restriktív) meghatározása sorolandó ide, mint kemény eszkőz. A legtöbb tervezési területen a területi és az ágazati szemlélet összefonódik. Nagyon lényeges, hogy azok az ágazati tervek, amelyeknek térségi kihatásuk van, területi szemléletben is koordináltak legyenek. Az ágazati szervek, mint külső tényezöket általában elhanyagolják a területi érdekeket. A területi tervezés számára problémát jelent, hogy rendszerint nincs hozzáférési lehetősége a szakmaspecifikus ágazati információkhoz. A terulletfejlesztési szerveknek, szemben a területi államigazgatási szervekkel, nincs kifejezett klientúrájuk. A területi tervezés eredményeit az érintett társadalmi csoportok 
csak kőzvetett módon, az azokat megvalósító ágazati vagy önkormányzati intézkedéseken keresztül érzékelik. Azaz nincs egy olyan egyértelmüen lehatárolható kedvezményezett kör, amelyre a döntéshozatal, mint politikai folyamat során támaszkodni lehetne. A területi államigazgatási szerveknek rendszerint részletes, relatíve rövid idöre kidolgozott célrendszerük és intézkedési koncepciojuk van, amelyek tơbbnyire politikai szempontból sürgősen megvalósítandók. Ezzel szemben a regionális tervek irikább absztraktak, hosszú távra szólóak, átlépik a napi politika időhorizontját. A regionális tervezésnek feladata az ellentétes érdekek kiegyenlítése, míg az ágazati tervek szakmaiságát - noha azok is gerjeszthetnek konfliktusokat - általában senki nem vonja kétségbe. Tehát megállapítható, hogy a területi tervezés pozíciója az ágazatokhoz képest meglehetósen gyenge (Benz 1982).

A törvényhozó a Tft.-ben helyénvalóan szabályozta a területi államigazgatási szervek feladatait (18. §): „,... a területfejlesztéssel és területrendezéssel összefüggő kormányzati feladatok végrehajtásában, érvényesítésének ellenőrzésében, a térségi fejlesztés és tervezés koordinálásában szakmai segítségnyújtással és információszolgáltatással, valamint hatósági ellenörzéssel vesznek részt." A terulleti és ágazati érdekek ősszehangoltságát hivatott biztosítani az érdekelt területi államigazgatási szervek képviselőinek állandó meghívotti státusza a megyei területfejlesztési tanács ülésein. A koordináció akkor válna teljessé, ha az ágazati érdekek megjelenítésének inverzeként a tơrvény a területi államigazgatási szervek számára kőtelezettséggé tette volna saját tervezési tevékenységük során a területfejlesztési koncepciók, programok figyelembevételét. Természetesen ez sem állna meg az eljárásjogi szabályok tisztázása nélkull, úm. a figyelembevétel idöpontja, intenzitása stb. Feltehetöleg nem visz kőzelebb a kétfajta érdekstruktúra kőzelítésének megoldásához a regionális fejlesztési tanácsok összetételére vonatkozó rendelkezés sem, amely összesen kilenc miniszter képviselöjének egyidejű részvételét biztosítja a tanács tevékenységében. Nem derül ki azonban, hogy mi a garanciája annak, hogy a későbbiekben az ágazatok magukévá teszik a regionális elveket. Ugyanígy kérdéses a kormányzati érdekek koordinált megjeleníthetósége is. A regionális fejlesztési tanácsok összetétele is rámutat arra, hogy a területfejlesztés intézményi struktúrájának alapelve, a decentralizáció nem tudott áttơrni a központi hatalom centralizáltságán. Ennek tưkrében valószínúleg érdemes lenne összekapcsolni a decentralizációt a dekoncentrációval, fơként a terủieti államigazgatási szervek regionalizálása során.

A régió/megye olyan tervezési egységnek tekintendő, amelynek egyik funkciója, hogy a terület-és gazdaságfejlesztési támogatások és intézkedések vonatkoztatási keretét adja. Másik funkciója ellenben abból adódik, hogy a tervezés és a terveket végrehajtó kőzigazgatás ơsszekötő kapcsa, ami rendszerint a tervezés és a kőzigazgatás integráciojának irányába mutat, hogy azután a kőzigazgatási régió létrehozásában oldódjék fel (Götz 1974). Magyarországon a régiónak, mint nem tisztán tervezési kategóriának a kezelése azért nem teljesen problémamentes, mert a területfejlesztési koncepciók és programok tervezési jogosultja a területfejlesztési tanács, míg a rendezési tervezés jogosultjai az ơnkormányzatok. A két alanyi kör szétválása alapjaiban megfoszt bennủnket az önkormányzati régió alapitásának számos elönyétöl. 


\section{Jegyzet}

${ }^{1}$ A tanulmány az OTKA 23003 számú kutatás keretében készült.

\section{Irodalom}

Benz, A. (1982) Regionalplanung in der Bundesrepublik Deutschland. (Eine empirische Untersuchung zur Organisation und Problemlðsungsfăhigkeit). Beiträge zum Siedlungs- und Wohnungswesen und zur Raumplanung Band 80. - Ernst, W-Hoppe, W.-Thoss, R. (Hrsg.), Munster, Selbstverlag des Institut fur Siedlungs- $u$. Wohnungswesen und Zentralinst für Raumplanung.

Bloch, A. (1987) Koordinierung raumrelevanter Planungen durch die Regionalplanung in NordrheinWestfalen. - Raumforschung und Raumordnung. 1-2. 11-16. o.

Erbguth, W. (1981) Zur Rechtsnatur von Planen und Programmen der Raumordnung und Landesplanung. - Deutsches Verwaltungsblatt. 12.550-558. 0.

Fritz-Viette, R. (1987) Regionalplanung in Hessen. - Raumforschung und Raumordnung. 1-2. 17-26. o.

Fürst, D. von (1987) Regionalplanung in Niedersachsen. - Raumforschung und Raumordmung. 1-2. 6-11. o.

Fürst, D. von-Ritter, E.-H. (1993) Landesentwicklungsplanung und Regionalplanung (Ein verwaltungswissenschaftlicher Grundriß). Dusseldorf, Werner-Verlag.

Götz, V. (1974) Staat und Kommunalkörperschaften in der Regionalplanung. Im Dienst an Recht und

Staat. Festschrift für Werner Weber zum 70. Geburtstag. - Schneider, H.- Götz, V. (Hrsg.), Berlin, Duncker-Humblot. 980-1001. 0.

Horváth Gy. (1998) Régiók az Európai Unióban. - Európai Tükör. 8. 4-23. o.

Kistenmacher, H.-Clev H-G. (1996). Das franzősische Raumordnungs- und Raumentwicklungsrahmengesetz (Raumordnungsgesetz). - Raumforschung und Raumordnung. 4. 265-276. o.

Mäding, H. (1987) Landerbericht Baden-Wurttemberg. - Raumforschung und Raumordnung. I-2. 49-55. o.

Mäding, H. (1992) Verwaltung im Wetbewerb der Regionen. Archiv für Kommunalwissenschaften. Deutsches Institut fur Urbanistik. Verlag W. Kohlhammer, 2. Halbjahresband. 205-219. o.

Muller, B. (1987) Regionalplanung in Bayern. - Raumforschung und Raumordnung. I-2. 32-39. o.

Pálné Kovács I. (1997) Merre halad a magyar vidék? A fejlesztési politika és a közigazgatás ellentmondásai a rendszerváltozás után. - Társadalmi Szemle. 12.3-15. o.

Rechnitzer J. (1998) Területfejlesztési stratégiák. Budapest-Pécs, Dialóg Campus.

\section{OUTLINE OF THE RELATIONSHIP BETWEEN SPATIAL PLANNING AND PUBLIC ADMINISTRATION, OR REGIONALISATION FROM THE VIEW OF SPATIAL PLANNING}

\section{EDIT PFEIL}

Hungarian public administration is facing the challenge of modernisation. One of the basic questions is the role of regions in the system of state in the process of EU enlargement. At the same time with the EU-conform establishment of the Hungarian institution of regional development, regions became regional development and statistical units. In the near future the answer has to be given to the following questions. Do the Hungarian regions have to integrate into the public administration? Do they have to become a governmental level with directly selected body? 
The study likes to approach this problem from the view of spatial planning, notdely from the aspect of institutions of regional planning. The presentation of institutional background of spatial planning in other countries in the first part of the study expresses the focus on the relationship between regional planning and public administration. There is a different relationship between local government, or state dominant regional planning and local governmental sphere and organisations of public administration.

There is an individual and particular institutional system of regional planning in Hungary from this point of view, because two separated structures has been established for development and planning. Strategic planning is settled to regional development councils in the level of regions and counties, but regional planning belongs to local governments. In Hungary the local governments have built up in the levels of settlements and counties, while sooner or later regional level has to become dominant in connection with regional development.

There are countries where administrative/local governmental level has the functions of planning regions. The analysis of foreign experiences prove that this countries both the administration and the planning decision making function are supplied by the same political body usually the direct elected body. There are no parallel duplicated organisations and structures only for regional planning. It is not merely saving, but also because the regional public bodies are capable to articulate the regional interests. There are independent planning regions from administrative regional division in federalised countries. In that case, the determination of planning regions is primarily based on the gravitation area of higher centres.

In Hungary planning regions are artificial formations. Borders of spatial planning and public administration are matched in the current middle level of local government (county), though they operate in two different bodies. In the process of public administration reform the regionalisation of public administration and the keeping of regional planning-statistical units may seemed a rationalised solution instead of the duplication of structures. Besides the strengthening of the county government in the current county level the regional development unit elimination could be proposed. 